
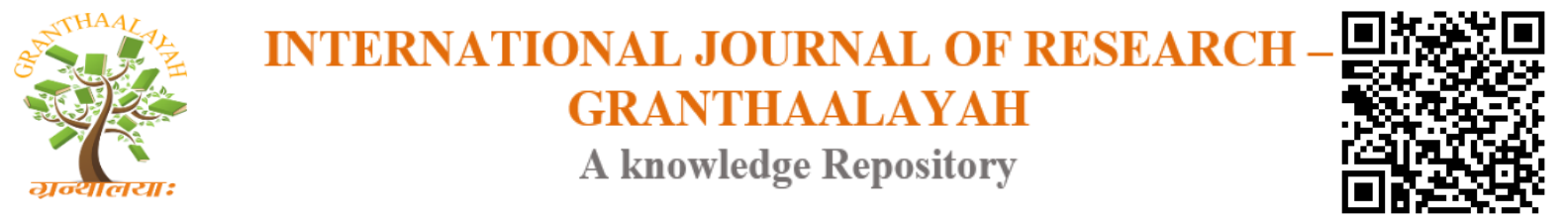

Social

\title{
LEADERSHIP QUALITIES AMONG THE B.ED. STUDENT TEACHERS IN COIMBATORE DISTRICT
}

\author{
V. Brindarani ${ }^{1}$, D. Geetha ${ }^{2}$ \\ ${ }^{1}$ M.Sc. M.Ed. Scholar, RVS College of Education Sulur, India \\ ${ }^{2}$ M.A, M.Ed Assistant Professor in Pedagogy of English, RVS College of Education Sulur, India
}

\begin{abstract}
Education is to improve humanity. Man becomes wise man through education. Education is a powerful instrument of social, economic and cultural transformation necessary for the realization of national goals. Leadership quality is considered as quality an integral part of the teacher education. Leader is one who makes his subordinate to do willingly what he wants. The efforts of subordinates are to be canalized in the right direction. As leaders, they are not only responsible for directing their subordinates but also responsible for the attainment of goals of education. One of the major objective of this study is to investigate Leadership Qualities among B.Ed., Student Teachers based on Gender, Religion, Types of Family, Medium of Study and Educational Qualification of Parents. The Sample 300 B.Ed., Student teachers from 10 colleges in Coimbatore District.
\end{abstract}

Keywords: Leadership Qualities; Student Teachers; Investigate; Colleges.

Cite This Article: V.Brindarani, and D. Geetha. (2018). "LEADERSHIP QUALITIES AMONG THE B.ED. STUDENT TEACHERS IN COIMBATORE DISTRICT.” International Journal of Research - Granthaalayah, 6(6), 97-100. 10.29121/granthaalayah.v6.16.2018.1340.

\section{Introduction}

The word 'leadership' has a wide assortment of meanings or interpretations or definitions. More often today than in the past, we find leader being thought of as resource person. Many of research workers and experts have studied about this term from their different views and some of them used it as an administrative, executive, evaluative, sense, qualities of an individual or supervisory behavior and some other used it in a mere limited sense. It is a form of social interaction or process of mutual stimulation between an individual and the members of his/her group. Leadership can be more properly referred to as a 'leader-follower' role. Here, the group may be an educational institution, or it may be other types of institution. So, leadership is the ability to influence a group towards the achievement of common goals or it is the process of influencing and supporting others to work enthusiastically towards achieving objectives. Particularly within the field of educational administration, the term 'leadership qualities' is a process or act of influencing the movements of 
an organized group in its efforts towards goal achievement. In this sense, leadership behavior refers to a relationship between persons or to the interplay among persons.

\section{Objectives of the Study}

Objectives are the main areas where the investigator will be conducting the study work. There are two main objectives conducting undertaken by the investigator in this study.

\subsection{General Objective}

To find out the significant score difference in the Leadership qualities among B.ED., student teachers.

\subsection{Specific Objectives}

To find out the significant score difference in the Leadership qualities among B.ED., student teachers based on

- Gender

- Religion

- Types of Family

- Medium of Study

- Educational Qualification Of Parents

\section{Hypothesis 1}

There is no significant mean score difference in B.Ed., student teachers leadership qualities with regard to Gender.

Table 1: Leadership Qualities with regard to Gender

\begin{tabular}{|l|l|l|l|l|l|l|l|}
\hline S.No. & Gender & N & Mean & S.D. & Table Value & t-value & Remarks \\
\hline 1 & Boys & 80 & 1.97 & 0.14 & 1.980 & 0.11 & NS \\
\hline 2 & Girls & 220 & 1.90 & 0.20 & & & \\
\hline
\end{tabular}

\section{Interpretation}

It is inferred from the above table that the calculated t-value 0.11 are less than the table value 1.98 at 0.05 level of significance. Hence, the null hypothesis is accepted.

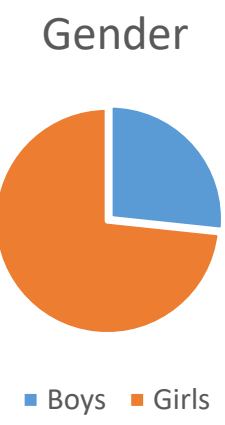




\section{Hypothesis 2}

There is no significant mean score difference in B.Ed., student teachers leadership qualities with regard to Type of Family.

Table 2: Leadership Qualities with regard to Type of Family

\begin{tabular}{|l|l|l|l|l|l|l|l|}
\hline S.No. & Type of Family & $\mathbf{N}$ & Mean & S.D. & Table Value & t-value & Remarks \\
\hline 1 & Nuclear & 197 & 1.93 & 0.16 & 1.980 & 0.07 & NS \\
\hline 2 & Joint & 103 & 1.91 & 0.19 & & & \\
\hline
\end{tabular}

\section{Interpretation}

It is inferred from the above table that the calculated t-value 0.07 are less than the table value 1.98 at 0.05 level of significance. Hence, the null hypothesis is accepted.

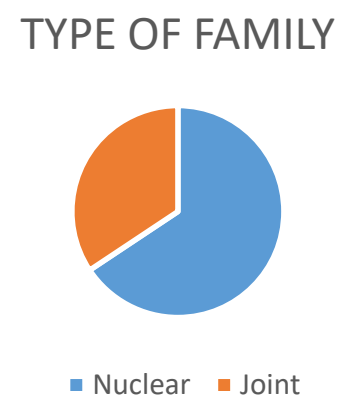

\section{Hypothesis 3}

There is no significant mean score difference in B.Ed., student teachers leadership qualities with regard to Medium of Study.

Table 3: Leadership Qualities with regard to Medium of Study

\begin{tabular}{|l|l|l|l|l|l|l|l|}
\hline S.No. & Medium of Study & $\mathbf{N}$ & Mean & S.D. & $\begin{array}{l}\text { Table } \\
\text { Value }\end{array}$ & t-value & Remarks \\
\cline { 1 - 6 } 1 & Tamil & 180 & 1.90 & 0.18 & 1.980 & 0.09 & NS \\
\hline 2 & English & 120 & 1.93 & 0.15 & & & \\
\hline
\end{tabular}

\section{Interpretation}

It is inferred from the above table that the calculated t-value 0.09 are less than the table value 1.98 at 0.05 level of significance. Hence, the null hypothesis is accepted.

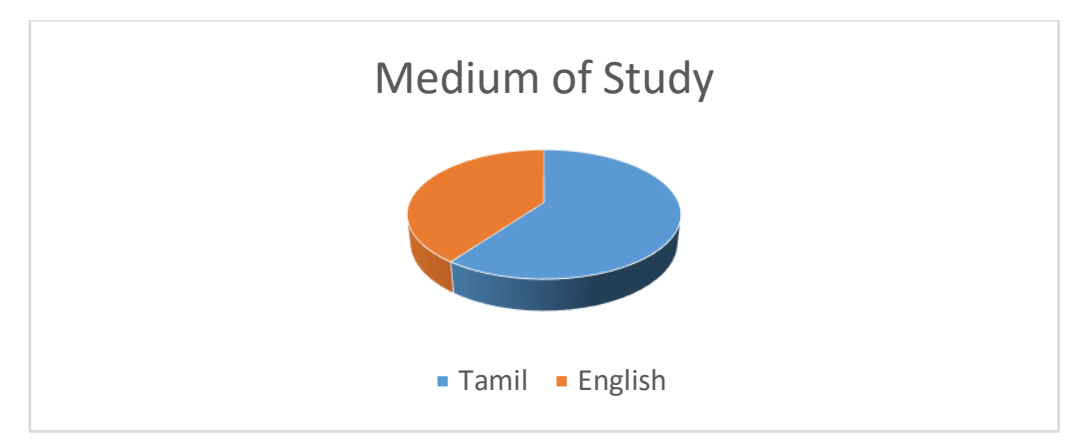




\section{Conclusion}

- The calculated t-value 0.11 are less than the table value 1.98 at 0.05 level of significance. Hence, the null hypothesis is accepted. There is no significant mean score difference in B.Ed., Student Teachers leadership qualities with regard to Gender.

- The calculated t-value 0.07 are less than the table value 1.98 at 0.05 level of significance. Hence, the null hypothesis is accepted. There is no significant mean score difference in B.Ed., Student Teachers leadership qualities with regard to Types of Family.

- The calculated t-value 0.09 are less than the table value 1.98 at 0.05 level of significance. Hence, the null hypothesis is accepted. There is no significant mean score difference in B.Ed., Student Teachers leadership qualities with regard to Medium of Study.

\section{References}

[1] Arsenalult, Paul. M (1998), Using the social constructive perspective to investigate charismatic leadership, vol.60, no.3, P:597

[2] Barr, Betty (2006), A study of the impact of leadership on secondary school climate. Vol.67, no.4, p: 1159

[3] Beukman, Theunis Lodewyk (2005), the effect of selected variables on leadership behaviour within the Framework of a transformational organization paradigm. Vol.67, no.8, P: 3183.

[4] Cheaupalakit, Panpim (2002), the leadership styles of male and female higher education administrators in Thailand. Vol.63, no.9, P:3065

[5] Clabough, Peter (2006), the relationship between principal leadership style, school climate and violence in middle school. Vol.67, no.8, P: 2826

[6] Fidanza, Dawn Muzeni (2005), Assessing Leadership styles of principals whose schools have won the National School Change Award. Vol.66, no.3, P: 841

[7] Geter, Kira Lashone (2005), Leadership behaviors of principals in integrating technology into teaching. Vol.67, no.5, P: 1599

[8] Gilbert, Janet (2000), the impact of leadership behavior on collaboration and management. Vol.61, no.1, P: $40 \mathrm{~A}$

[9] Jabati, Frank Maada (1997), Leadership behavior and organizational outcomes in farmer cooperatives as measured by the multifactor Leadership Questionnaire. Vol.58, no.8, P: 2958.

[10] Letcher, Maureen (2006), a study of the relationship between leadership and school climate in rural secondary schools. Vol.67, no.4, P: 1283.

[11] Mulligan, Deborah R (2001), Knowledge-sharing leadership: sharing of knowledge in relation to leadership. Vol.62, no.2, P: 670.

*Corresponding author.

E-mail address: brindacbe10@ gmail.com 